\title{
EPIDEMIOLOGICAL AND CLINICAL CHARACTERISTICS, CAUSATIVE DRUGS, AND DIAGNOSTIC CHALLENGES OF FIXED DRUG ERUPTION IN ELDERLY PATIENTS: IS BULLOUS TYPE A MORE COMMON CLINICAL PHENOTYPE?
}

\author{
YAŞLI HASTALARDA FIKS ILAÇ ERÜPSIYONUNUN EPIDEMIYOLOJIK VE KLINIK \\ ÖZELLIKLERI, ETKEN ILAÇLAR VE TANISAL ZORLUKLAR: BÜLLÜ TIP DAHA SIK \\ GÖRÜLEN BIR KLINIK FENOTIP MIDIR?
}

\author{
Goncagül BABUNA KOBANER ${ }^{10}$, Esen ÖZKAYA² (D) \\ ${ }^{1}$ Istanbul University, Istanbul Faculty of Medicine, Department of Dermatology and Venereology, İstanbul, Turkey
}

ORCID IDs of the authors: G.B.K. 0000-0002-0985-5027; E.Ö. 0000-0002-9585-9509

Cite this article as: Babuna Kobaner G, Ozkaya E. Epidemiological and clinical characteristics, causative drugs, and diagnostic challenges of fixed drug eruption in elderly patients: is bullous type a more common clinical phenotype? J Ist Faculty Med 2021;84(4):559-67. doi: 10.26650/IUITFD.2021.934957

\section{ABSTRACT}

Objective: The present study aimed to evaluate the epidemiological and clinical features, causative drugs, and diagnostic challenges of Fixed drug eruption (FDE) in elderly patients.

Material and Methods: In this single-center, retrospective, cross-sectional study, we evaluated data of all consecutive adult patients (aged $>18$ years) with an established diagnosis of FDE between 1996-2018 in our tertiary referral center in Turkey. Elderly patients who were aged $\geq 60$ years at the time of diagnosis were allocated to the study.

Results: Among 182 adult FDE patients, 14 (7.7\%) patients (male/ female=1/1.8) were in the elderly group (mean age=66.1 \pm 6.9 years). Fix drug eruption was induced by intermittently taken drugs in all patients, $50 \%$ of whom had polypharmacy (concurrent use of $\geq 5$ medications). Trimethoprim-sulfamethoxazole (42.9\%) and non-steroidal anti-inflammatory drugs (35.7\%) were the main causative drugs, while ornidazole was a remarkable novel FDE inducer since 2011. Fix drug eruption was mostly located on the trunk and extremities. Mucosal involvement was less frequent. Ten (71.4\%) patients had bullous FDE (BFDE). There were no statistically significant differences between the gender and mean ages of the patients with and without BFDE.

Conclusion: Our long-term experience demonstrated that FDE may also affect elderly patients. Most of the patients had BFDE raising the question of whether the bullous type is a more common clinical phenotype in these patients. Among the important

\section{ÖZET}

Amaç: Bu çalışmanın amacı, yaşlı hastalarda fiks ilaç erüpsiyonunun (FIE) epidemiyolojik ve klinik özelliklerinin, etken ilaçlarının ve tanısal zorluklarının değerlendirilmesidir.

Gereç ve Yöntemler: Tek merkezli, retrospektif kesitsel çalışmamızda, Türkiye'de üçüncü basamak bir referans merkezi Alerji kliniğinde, 1996-2018 yılları arasında FiE tanısı konulmuş olan erişkin hastaların (>18 yaş) dosyaları incelenmiştir. FiE tanısı konulduğu sırada 60 yaş ve üzerinde olan yaşlı hastalar çalışmaya dahil edilmişlerdir.

Bulgular: Toplam 182 erişkin FiE hastası arasından, $14(\% 7,7)$ hasta (erkek/kadın=1/1,8) yaşlı grubundaydı (ortalama yaş=66,1 $\pm 6,9$ ). Fiks ilaç Erüpsiyonu, hastaların tümünde aralıklı olarak kullanılan ilaçlara bağlı geliş̧mişti. Bu hastaların \%50' sinde polifarmasi (eş zamanlı $\geq 5$ ilaç kullanımı) mevcuttu. Fiks ilaç Erüpsiyonunun en sık etkenleri, trimetoprim-sülfametoksazol $(\% 42,9)$ ve nonsteroidal antienflamatuvar ilaçlar $(\% 35,7)$ olmakla birlikte 2011 yılından itibaren ornidazol de yeni ve dikkat çekici bir Fiks ilaç Erüpsiyonu etkeni olarak karşımıza çıkmıştı. Fiks ilaç Erüpsiyonu lezyonları sıklıkla gövde ve ekstremitelerde yerleşmekteydi. Mukozal tutulum daha nadirdi. On $(\% 71,4)$ hastada büllü FiE (BFIE) saptandı. Büllü FiE olan ve olmayan hastalar arasında cinsiyet ve ortalama yaş açısından istatistiksel olarak anlamlı farklılıklar saptanmadı.

Sonuç: Uzun-dönem klinik tecrübemiz ışığında, FiE yaşlı kişilerde de görülebilen ve hastaların büyük bir çoğunluğunda büllü

Corresponding author/iletişim kurulacak yazar: profeo@istanbul.edu.tr

Submitted/Başvuru: 08.05.2021 • Revision Requested/Revizyon Talebi: 18.05.2021 •

Last Revision Received/Son Revizyon: 04.06.2021 • Accepted/Kabul: 07.06.2021 • Published Online/Online Yayın: 24.09 .2021 
diagnostic challenges of FDE in this age group, e.g., polypharmacy, multimorbidity, recall problems, cognitive disorders, frailty, and immunosenescence, BFDE should also be kept in mind as it may clinically mimic Stevens-Johnson syndrome/toxic epidermal necrolysis, and autoimmune bullous diseases.

Keywords: Drug eruptions, aged, vesiculobullous skin diseases, trimethoprim-sulfamethoxazole drug combination, non-steroidal anti-inflammatory agents, ornidazole morfolojinin (BFiE) eşlik ettiği bir ilaç döküntüsü olarak karşımıza çıkmıştır. Bu durum, BFiE'nin bu yaş grubunda sık görülen bir klinik fenotip mi olduğu sorusunu akla getirmiştir. BFIE'nin klinik olarak Stevens-Johnson sendromu/toksik epidermal nekroliz veya otoimmün büllü hastalıklar ile ayırıcı tanıya girmesi tanıda zorluklara yol açabilmektedir. Fiks ilaç Erüpsiyonu şüphesi olan yaşlı hastalarda polifarmasi, multimorbidite, hafıza problemleri, kognitif bozukluklar, kırılganlık ve immün sistemin yaşlanması (immunosenescence) gibi tanıyı güçleştirebilecek durumlar arasında BFiE de akla gelmelidir.

Anahtar Kelimeler: Illaç erüpsiyonları, yaşlı, büllü deri hastalıkları, trimetoprim-sülfametoksazol, non-steroidal antienflamatuvar ilaçlar, ornidazol

\section{INTRODUCTION}

Population ageing is a global phenomenon driven by decreasing fertility rates and remarkable improvements in life expectancy $(1,2)$. According to The United Nations, the share of the world's population over 60 years is growing rapidly and is expected to reach up to $21.2 \%$ by 2050 (3). This ongoing demographic transformation poses special challenges for clinicians worldwide.

With advancing age, medication use is steadily rising in the elderly, highlighting the need for further research on adverse cutaneous drug reactions (ACDRs) which are often underreported in this age group (4). Compared with young adults, older people are at an increased risk for developing ACDRs, due to the high prevalence of multimorbidity, polypharmacy, and age-related changes in pharmacokinetics and pharmacodynamics (4-6). Moreover, evaluation of elderly patients with ACDRs may be challenging, especially of those with cognitive impairment, frailty, and immunosenescence. Most of the ACDRs are not life-threatening and spontaneously resolve after the discontinuation of the responsible agent. However, delayed diagnosis may result in recurrences which constitute an important source of morbidity, further decreasing the quality of life in elderly individuals (6).

Fixed drug eruption (FDE) is one of the most common drug eruptions in Turkey (7). It is a T-cell mediated (type IVc) hypersensitivity reaction characterized by the recurrence of skin and/or mucosal lesions at the same sites, following each exposure to the offending drug $(7,8)$. Its clinical spectrum is quite broad, ranging from typical solitary or multiple, sharply defined, erythematous or violaceous plaques to various atypical variants and even generalized bullous lesions $(7,8)$. The inducers of FDE show significant geographical and temporal variations depending on the most frequently used drugs in a given time period (9). Fix drug eruption (FDE) may occur throughout life; however, aside from a few anecdotal case reports, there is lack of data regarding its characteristics in the older population (10-12).
Thepresentstudyaimedtoinvestigatetheepidemiological and clinical features, and culprit drugs of FDE in the elderly, with a special focus on bullous FDE (BFDE), which is a rare, but challenging FDE variant clinically mimicking severe and potentially life-threatening drug reactions, such as Stevens-Johnson syndrome and toxic epidermal necrolysis, and autoimmune bullous diseases, such as pemphigus vulgaris and bullous pemphigoid.

\section{MATERIAL AND METHODS}

In this single-center, retrospective, cross-sectional study, we evaluated the data of all the consecutive adult patients (aged >18 years) with FDE between 1996 and 2018 in our Allergy unit, a tertiary referral center in Turkey. Exclusion criteria were pediatric patients (aged $\leq 18$ years) and patients in whom oral/topical provocation tests could not be performed, or failed to identify the causative drugs.

Among a total of 182 adult patients with an established diagnosis of FDE, only those who were $\geq 60$ years of age at the time of diagnosis were allocated to the study. In all patients, FDE was diagnosed upon the results of oral/ topical provocation tests which were performed during the remission phase of FDE, after a verbal or written informed consent had been obtained.

For the oral provocation test, a $1 / 8$ dose of a certain drug was initiated, gradually increasing to $1 / 4,1 / 2$, and one full dose at 12 to 24 hour intervals. A positive test result was characterized by flaring up of the old FDE sites showing erythema and/or edema and accompanying itching and/or burning that started within 10-30 minutes up to a few hours after taking the test doses of the suspected drug (7). On the other hand, topical provocation tests were performed by applying the suspected drugs at concentrations of $1-10 \%$ in white petrolatum to the old FDE sites as occlusive or open patch testing, as described before (7). The development of erythema with/without induration in an old FDE lesion within 24 hours and persistence for at least 6 hours was considered a positive test result (7). 
The files of the patients were analyzed regarding demographic, clinical, histopathological features, and causative drugs, and for patients with trimethoprim-sulfamethoxazole-induced FDE, additionally for the presence of genetic markers, i.e., HLA-A30 B13 Cw6 haplotype, and HLA-B55 antigen (split of B22). A lymphocytotoxicity assay was performed for Class I HLA typing (13).

Generalized FDE was defined as the presence of widespread FDE lesions involving $\geq 10 \%$ body surface area on $\geq 3$ of 6 different anatomic sites, including the head and neck, anterior trunk, posterior trunk, upper extremities, lower extremities, and genitalia (14).

This study was approved by the local ethics committee (Date: 18.03.2021, No: 139758), and conducted in accordance with the ethical standards of the Declaration of Helsinki.

\section{Statistical analysis}

Statistical analysis was performed using SPSS Nersion 22, IBM). Quantitative data were expressed as means \pm standard deviation (SD) and qualitative data as number ( $\mathrm{n}$ ) and percentage (\%). Means were compared using Student's t-test (for normal distributions) or Mann-Whitney $U$ test (for non-normal distributions), while frequencies were compared using the chi-square or Fisher's exact test. A 2-tailed P-value $<0.05$ was accepted for statistical significance.

\section{RESULTS}

Of 182 adult patients with FDE, 14 (7.7\%) patients (male/ female ratio 1/1.8) were in the elderly group. The mean age of the patients was $66.1 \pm 6.9$ years. Two (14.3\%) patients had a history of allergic rhinoconjunctivitis, while none of the patients had a family history of FDE. The characteristic features of 14 elderly patients with FDE are presented in Table 1.

The duration of the disease ranged from 1 month to 240 months, with a median of 18 months. In 12 (85.7\%) patients, the disease duration was $\geq 1$ year at the time of diagnosis. The number of attacks ranged from $1(n=1)$ to $10(n=2)$, with a median of 3 . Seven (50\%) patients reported an increase in the number and/or size of FDE lesions with subsequent attacks.

Table 1: Characteristic features of 14 elderly patients with an established diagnosis of fixed drug eruption between 1996 and 2018

\begin{tabular}{|c|c|c|c|c|c|c|c|c|}
\hline 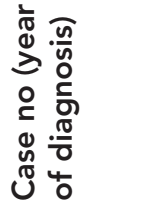 & 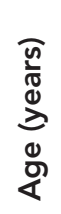 & 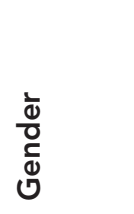 & $\begin{array}{l}\text { वे } \\
\frac{0}{2}\end{array}$ & 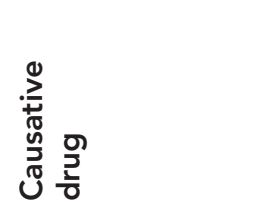 & 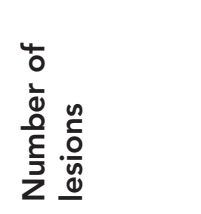 & 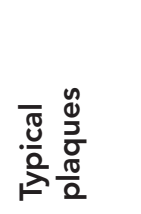 & $\begin{array}{l}\stackrel{0}{\pi} \\
\stackrel{\bar{J}}{\bar{D}} \\
\end{array}$ & 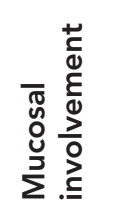 \\
\hline 1 (1996) & 66 & Male & No & $\begin{array}{l}\text { Trimethoprim-sul- } \\
\text { famethoxazole }\end{array}$ & $2-10$ & Yes & Yes & No \\
\hline $2(1996)$ & 60 & Male & No & $\begin{array}{l}\text { Trimethoprim-sul- } \\
\text { famethoxazole }\end{array}$ & Solitary & Yes & No & No \\
\hline $3(1997)$ & 62 & Female & No & Naproxen & $2-10$ & Yes & Yes & Oral \\
\hline $4(1997)$ & 60 & Female & No & $\begin{array}{l}\text { Trimethoprim-sul- } \\
\text { famethoxazole }\end{array}$ & Solitary & Yes & No & No \\
\hline 5 (1999) & 67 & Female & $A R$ & $\begin{array}{l}\text { Trimethoprim-sul- } \\
\text { famethoxazole }\end{array}$ & $>10$ & Yes & Yes & No \\
\hline $6(1999)$ & 60 & Male & No & $\begin{array}{l}\text { Trimethoprim-sul- } \\
\text { famethoxazole }\end{array}$ & Solitary & Yes & Yes & Genital \\
\hline 7 (2004) & 65 & Female & No & Dipyrone & $>10$ & Yes & Yes & No \\
\hline $8(2005)$ & 60 & Female & No & Piroxicam & $2-10$ & Yes & Yes & Oral \\
\hline $9(2008)$ & 68 & Male & No & $\begin{array}{l}\text { Trimethoprim-sul- } \\
\text { famethoxazole }\end{array}$ & $2-10$ & Yes & Yes & Genital \\
\hline 10 (2008) & 60 & Male & $A R$ & Indomethacin & Generalized & Yes & No & No \\
\hline $11(2011)$ & 77 & Female & No & Ornidazole & Generalized & Purpuric & Yes & No \\
\hline 12 (2016) & 72 & Female & No & Naproxen & $>10$ & Yes & Yes & No \\
\hline 13 (2017) & 67 & Female & No & Dimenhydrinate & $>10$ & Yes & Yes & Genital \\
\hline 14 (2018) & 82 & Female & No & Ornidazole & Generalized & Yes & No & No \\
\hline
\end{tabular}

AR: Allergic rhinoconjunctivitis 
Before referral to our clinic, FDE lesions of seven patients had been clinically diagnosed as drug eruption of an unknown nature $(n=2)$, eczema $(n=1)$, eosinophilic cellulitis $(n=1)$, Sweet syndrome $(n=1)$, pemphigus and erythema multiforme $(n=1)$, and mycosis fungoides $(n=1)$.

In all patients, the diagnosis of FDE was based upon the results of oral provocation tests which revealed a reactivation of old lesions between 30 minutes and 12 hours, following the intake of the responsible drug. Six patients also underwent topical provocation testing which was positive in only one of them. Histopathological examination was performed in eight patients and showed findings consistent with FDE, including an interface dermatitis characterized by dyskeratosis, basal cell vacuolar degeneration, melanophages in the upper dermis, and perivascular mononuclear inflammatory infiltration.

The main cause of FDE in elderly patients was trimethoprim sulfamethoxazole $(n=6)$ which was used for the treatment of infections (urinary tract infection, bronchitis, and tooth infection) or postoperative

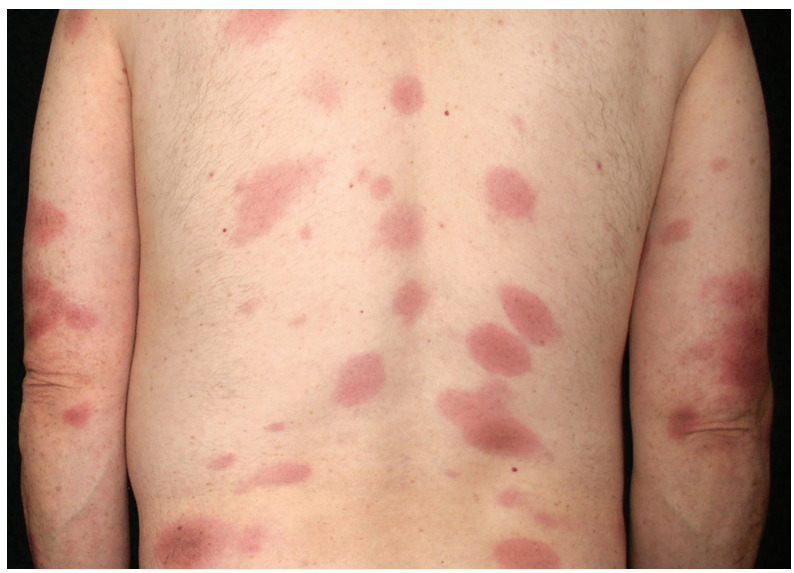

Figure 1: Typical plaque lesions of fixed drug eruption on the trunk

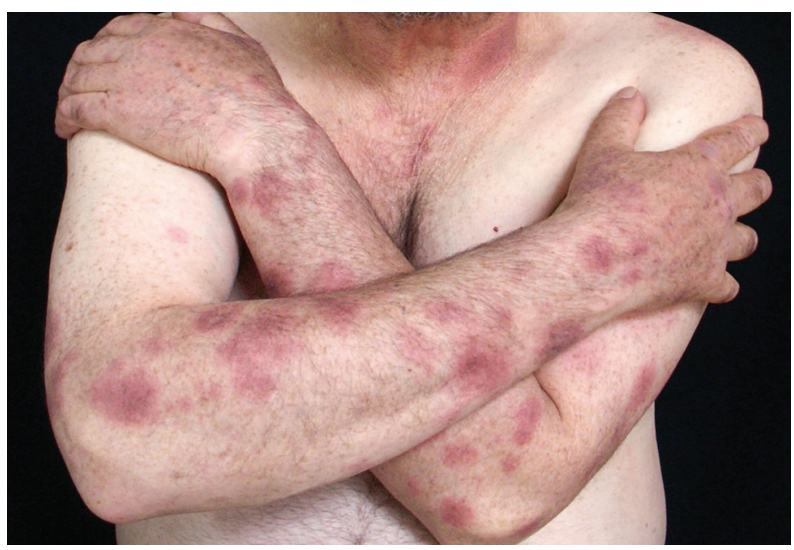

Figure 2: Typical plaque lesions of fixed drug eruption on the upper extremities infection prophylaxis. The second most common cause was nonsteroidal anti-inflammatory drugs (NSAIDs) comprising naproxen $(n=2)$, dipyrone $(n=1)$, piroxicam $(n=1)$, and indomethacin $(n=1)$, mainly administered for headache and arthralgia. Other causes included ornidazole $(n=2)$ and dimenhydrinate $(n=1)$, which were used to treat urinary tract infection and diverticulitis, and motion sickness, respectively. Between 1996 and 2003, the main culprit drug was trimethoprimsulfamethoxazole $(5 / 6=83.3 \%)$ which was superseded by NSAIDs (4/8=50\%) between 2004 and 2018.

More than half $(n=4 / 6 ; 66.7 \%)$ of the patients with trimethoprim-sulfamethoxazole-induced FDE were males, while more than $3 / 4(n=4 / 5 ; 80.0 \%)$ of the patients with NSAIDs-induced FDE were females. However, these differences showed no statistical significance.

Three patients had solitary lesions located on the cheek, foot, and penis, respectively, induced by trimethoprim-sulfamethoxazole. On the other hand, three patients had generalized FDE caused by ornidazole $(n=2)$ and indomethacin $(n=1)$.

FDE presented with typical sharply defined, erythematous to violaceous plaque lesions in all patients (Figure 1 and Figure 2), except for one patient who had purpu-

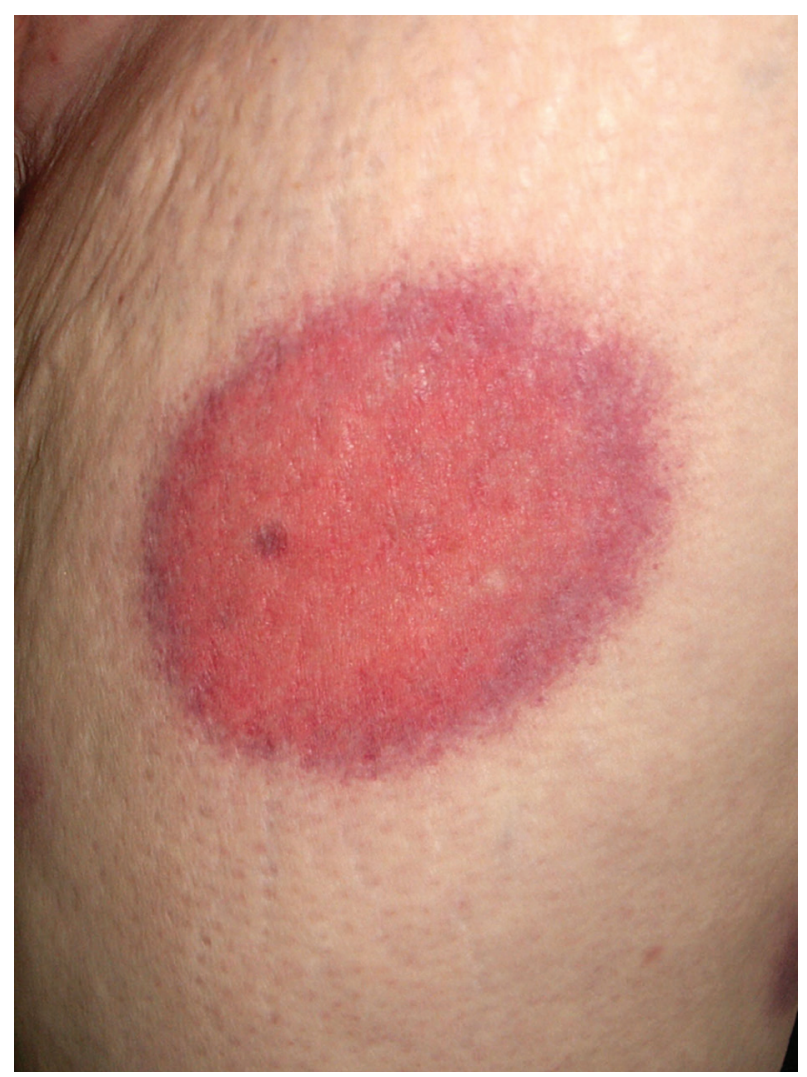

Figure 3: Purpuric fixed drug eruption on the left upper thigh 
ric plaques (Figure 3). All patients suffered from pruritus which was accompanied by a burning sensation in 12 patients. In nearly all patients ( $n=13)$, FDE lesions healed with postlesional hyperpigmentation.

Bullous skin lesions overlying plaques (Figure 4) were observed in 10 (71.4\%) patients. Bullae were present since the first attack $(n=8)$, or developed during the subsequent attacks $(n=2)$. The main causative drugs were trimethoprim-sulfamethoxazole $(n=4)$ and NSAIDs $(n=4)$, followed by dimenhydrinate $(n=1)$ and ornidazole $(n=1)$. Generalized bullae were seen in only one patient with

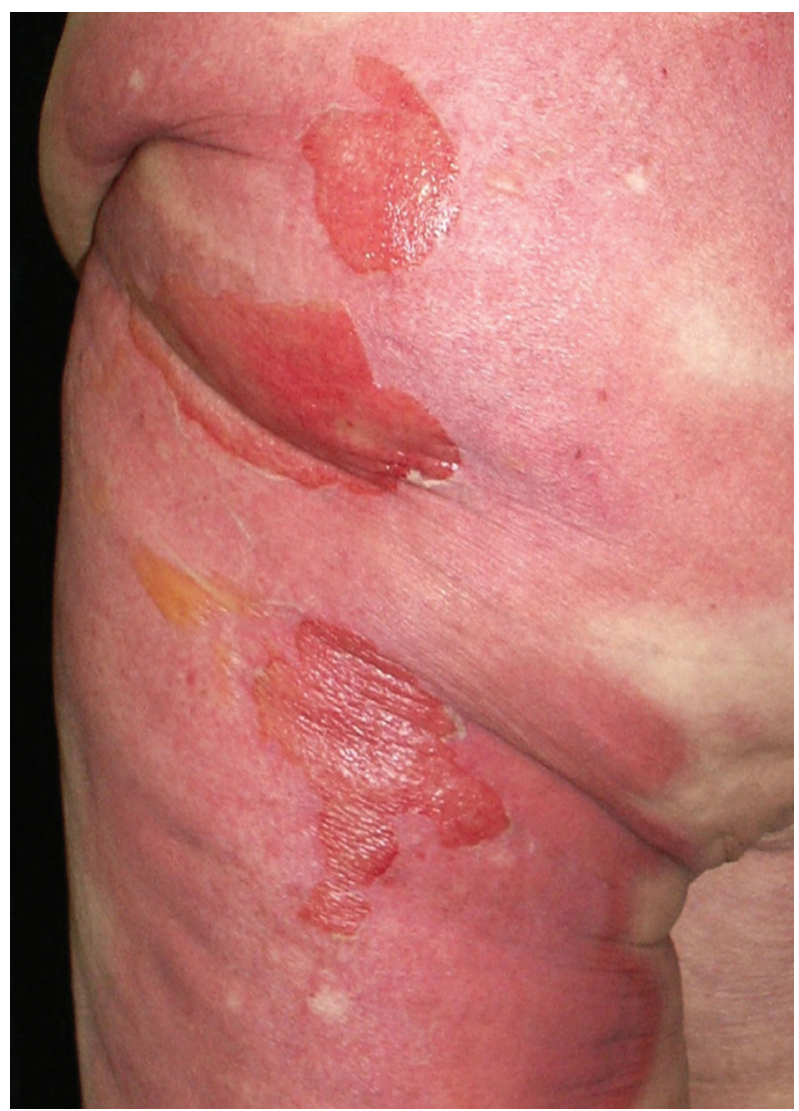

Figure 4: Bullous fixed drug eruption on the left upper thigh ornidazole-induced FDE. Two patients with BFDE had concurrent bullous/erosive oral mucosal lesions. There were no statistically significant differences between the patients with and without BFDE with respect to the mean age, gender, and presence of atopy (Table 2).

Nine patients (64.3\%) had skin lesions only, while 4 (28.6\%) patients had coexistent skin and mucosal lesions, and one patient (7.1\%) had mucosal lesions only. Localization and causative drugs of FDE are presented in Table 3.

With regard to skin involvement $(n=13)$, the most commonly involved sites were the trunk and extremities $(n=7)$ with a significant involvement of hands $(n=7)$ and feet $(n=4)$. Some patients showed specific patterns of skin involvement, such as finger/toe webs due to trimethoprim-sulfamethoxazole $(n=3)$, naproxen $(n=1)$, and dipyrone $(n=1)$, vermillion border of lips due to trimethoprim-sulfamethoxazole $(n=1)$ and naproxen $(n=1)$, nasal philtrum due to dipyrone $(n=1)$, eyelid due to trimethoprim-sulfamethoxazole $(n=1)$, and inner eye canthus due to dipyrone $(n=1)$.

Genital FDE was observed in three patients. Two patients had penile involvement due to trimethoprimsulfamethoxazole, whereas one patient had vulvar involvement due to dimenhydrinate. Penile involvement was the sole presentation of FDE in one patient. On the other hand, oral mucosal FDE was observed in two female patients with multiple bullous/erosive lesions. One patient had buccal mucosa involvement due to naproxen, while the other patient had buccal mucosa, hard palate, and tongue involvement due to piroxicam.

With regard to the results of Class I HLA typing, none of the patients with trimethoprim-sulfamethoxazole-induced FDE were positive for HLA-A30 B13 Cw6 haplotype, or HLA-B55 antigen.

\section{DISCUSSION}

To date, there have been no studies specifically focusing on FDE in the elderly population. Thus, our 23-year clinical experience presented herein may contribute to shed light on the characteristic features of FDE in this special age group with unique challenges and needs.

Table 2: Characteristics of elderly patients with and without bullous fixed drug eruption

\begin{tabular}{lccc}
\hline & \multicolumn{3}{c}{ Type of fixed drug eruption } \\
\cline { 2 - 4 } Characteristics of the patients & Bullous & Non-bullous & p-value \\
\hline Age (years), mean \pm SD & $\mathbf{n = 1 0}$ & $65.5 \pm 11$ & $0.311^{*}$ \\
Male/female, $n(\%)$ & $66.4 \pm 5.3$ & $2 / 2(50 / 50)$ & $0.580^{\star \star}$ \\
Atopy, $n$ (\%) & $3 / 7(30 / 70)$ & $1(25)$ & $0.505^{\star \star}$ \\
\hline
\end{tabular}

SD: Standard deviation, *Mann-Whitney $U$ test, ${ }^{\star \star}$ Fisher's exact test 
Table 3: Localization and causative drugs of FDE in elderly patients

\begin{tabular}{|c|c|}
\hline Characteristics & Total $n=14$ \\
\hline Distribution of FDE lesions & Skin only (9), skin and mucosa (4), mucosa only (1) \\
\hline \multicolumn{2}{|l|}{ Skin lesions $(n=13)$} \\
\hline $\begin{array}{l}\text { *Localization ( } \mathbf{n}) \\
\text { Trunk and extremities (7) } \\
\text { Hands (7) } \\
\text { Feet (4) } \\
\text { Lips (2) }\end{array}$ & $\begin{array}{l}\text { Causative drug ( } \mathbf{n}) \\
\text { Ornidazole (2)/dipyrone (1)/trimethoprim-sulfamethoxazole (1)/ } \\
\text { piroxicam (1)/indomethacin (1)/dimenhydrinate (1) } \\
\text { Trimethoprim-sulfamethoxazole (3)/naproxen (2)/piroxicam (1)/orni- } \\
\text { dazole (1) } \\
\text { Trimethoprim-sulfamethoxazole (3)/ornidazole (1) } \\
\text { Trimethoprim-sulfamethoxazole (1)/naproxen (1) }\end{array}$ \\
\hline Neck (1) & Ornidazole (1) \\
\hline $\begin{array}{l}\text { Specific pattern ( } \mathbf{n} \text { ) } \\
\text { Finger/toe webs (5) } \\
\text { Vermillon border (2) } \\
\text { Nasal philtrum (1) } \\
\text { Eyelid (1) } \\
\text { Inner eye canthus (1) }\end{array}$ & $\begin{array}{l}\text { Causative drug ( } \mathbf{n}) \\
\text { Trimethoprim-sulfamethoxazole (3)/naproxen (1)/dipyrone (1) } \\
\text { Trimethoprim-sulfamethoxazole (1)/naproxen (1) } \\
\text { Dipyrone (1) } \\
\text { Trimethoprim-sulfamethoxazole (1) } \\
\text { Dipyrone (1) }\end{array}$ \\
\hline \multicolumn{2}{|l|}{ Genital mucosal lesions $(n=3)$} \\
\hline $\begin{array}{l}\text { Localization (n) } \\
\text { Penis (2) } \\
\text { Vulva (1) }\end{array}$ & $\begin{array}{l}\text { Causative drug ( } \mathbf{n}) \\
\text { Trimethoprim-sulfamethoxazole (2) } \\
\text { Dimenhydrinate (1) }\end{array}$ \\
\hline \multicolumn{2}{|l|}{ Oral mucosal lesions $(n=2)$} \\
\hline $\begin{array}{l}\text { Localization ( } n \text { ) } \\
\text { Buccal mucosa (1) } \\
\text { Buccal mucosa and hard palate and tongue (1) }\end{array}$ & $\begin{array}{l}\text { Causative drug (n) } \\
\text { Naproxen (1) } \\
\text { Piroxicam (1) }\end{array}$ \\
\hline
\end{tabular}

*The total number is $>13$ as more than one skin site was involved in most of the patients.

Our study is the first to show that FDE, although mainly reported in young adults, is also a common type of drug eruption among the elderly. The share of elderly patients was nearly $8 \%(n=14 / 182)$ in our study. We assume that this value may further increase in the near future, as the older population continues to grow in Turkey as well. Moreover, although FDE usually has no gender preference, a female predominance in our study ( $n=9 / 14$; 64.3\%) as well as in previously reported elderly cases $(n=3 / 4 ; 75 \%)$ was remarkable $(7,10-12)$.

Trimethoprim-sulfamethoxazole (42.9\%) and NSAIDs (35.7\%) were the most common causative drugs of FDE in our elderly patients. Although trimethoprimsulfamethoxazole was the main culprit in the earlier years of the study, it was superseded by NSAIDs since the year 2004, following the decline in trimethoprimsulfamethoxazole use in Turkey, as previously reported (9). The high prevalence of NSAIDs-induced FDE was not surprising, as NSAIDs are among the most commonly prescribed medications for the management of pain and inflammation in this age group (15). A study based on data from the Norwegian Prescription Database showed that $7.3 \%$ of all elderly individuals aged $>60$ years filled at least one NSAID prescription in a one-year period (16).

In our experience, ornidazole was a remarkable novel FDE inducer since the year 2011, in concordance with the findings of a previous study from our clinic (9). The prevalence of ornidazole-induced FDE in the present series was $14.3 \%(n=2)$. Nevertheless, it is important to note that it was responsible for $66.7 \%$ of all generalized FDE (GFDE) cases, including the case of generalized bullous FDE (GBFDE) accompanied by atypical purpuric plaques. Ornidazole-induced FDE has been mainly reported from India and Turkey since the year 2005, reflecting its broad use in these countries for genitourinary infections and intestinal amoebiasis, respectively $(9,17-22)$. Compared with these cases, our patients (aged 77 and 82 years) were the oldest ones. Although ornidazole is a relatively newer 5-nitroimidazole derivative with a high safety profile, our experience along with the literature data indicate that it is an emerging inducer of FDE and should be used with caution, especially in elderly patients.

Polypharmacy is one of the biggest challenges in the identification of the causative drugs of FDE among the 
elderly. Nevertheless, its definition is still a matter of debate. According to the World Health Organization (2019), polypharmacy is often defined as the routine use of five or more medications, including over-the-counter, prescription, and/or traditional and complementary medicines (23). A recent comprehensive review demonstrated that the prevalence of polypharmacy in older adults ranged from $4 \%$ to over $96.5 \%$ across various studies, according to the definition, age group, healthcare setting, and region (24). Yet, all studies included in that review showed an increasing prevalence of polypharmacy in older adults over time (24). In the present study, on the other hand, half of the patients $(n=7)$ were using $\geq 5$ medications and $21.4 \%$ of the patients ( $n=3$ ) even $\geq 10$ medications (including both the regularly used drugs for comorbidities and intermittently used drugs for infections, pain management, etc.). Interestingly, in all patients, FDE was induced by intermittently taken antibiotics, NSAIDs, or dimenhydrinate. We believe that this is an important finding which may guide clinicians when conducting a medication review. Intermittent use of prescribed or overthe-counter medications should always be questioned in elderly patients with suspected FDE.

In the present study, FDE lesions were mostly located on the trunk and extremities (50\%) with a frequent acral (hands and/or feet) involvement. On the other hand, involvement of genital (21.4\%) and oral mucosa (14.3\%) was relatively low when compared with the results of previous studies from our clinic on FDE patients including younger adults $(25,26)$. All patients were suffering from disturbing pruritus, accompanied by a burning sensation in most of them. Xerosis and other age-related changes in skin could also have contributed to severe pruritus in these patients (27). Most patients had a disease duration of $\geq 1$ year at the time of diagnosis, and experienced recurrent attacks which induced an increase in the number and/or size of FDE lesions in half of the patients. Taken together, these findings highlight the importance of early diagnosis of FDE to prevent further increase in disease severity, and to preserve the quality of life in elderly patients.

As a striking finding, most patients in this study had BFDE. Bullae had been present since the first attack in the majority, and developed during the subsequent attacks in two patients. BFDE is a rare and severe type of FDE that clinically presents with localized or generalized blisters or erosions overlying plaque lesions on the skin (28). The frequency of BFDE ranged from $29.6 \%$ to $36.6 \%$ across various studies including heterogeneous age groups from Tunisia, India, and Korea, whereas it was $50.8 \%$ in a nationwide retrospective multicentric study from France (28-32). Compared with these literature data, our study presents the highest frequency $(71.4 \%)$ of BFDE, raising the question of whether the bullous type is a more common clinical subtype among the elderly. Further pro- spective large studies on elderly patients with FDE are warranted to confirm this potential association between BFDE and older age.

Diagnosing FDE is usually straightforward due to its unique clinical properties. Site-specific recurrence of the lesions is the diagnostic hallmark of FDE. However, bullous type, particularly GBFDE, may pose a big diagnostic challenge in elderly patients as it may mimic severe and potentially life-threatening drug reactions, such as Stevens-Johnson syndrome and toxic epidermal necrolysis, and autoimmune bullous diseases, such as pemphigus vulgaris and bullous pemphigoid $(28,33)$. To date, four elderly cases with FDE have been reported in literature (1012). They presented almost exclusively with GBFDE, except a 75-year old male with multiple plaque lesions due to ivermectin (10). GBFDE was induced by the influenza vaccine in a 67-year-old female, whereas metamizole was the causative drug in two female patients, aged 83 and 91 years, respectively $(11,12)$. These data along with our findings highlight that FDE may present with bullous or generalized bullous lesions even in the late elderly. Thus, awareness of this clinical heterogeneity of FDE remains crucial in preventing misdiagnosis which may lead to recurrent attacks, irrelevant investigations, and overtreatments in this fragile age group.

Evaluation of elderly patients with FDE has special difficulties. First of all, obtaining a comprehensive medication history may be challenging in this age group, due to the relatively high prevalence of self-medication (including over-to-counter or herbal medications), polypharmacy, recall problems, and cognitive disorders, ranging from mild impairment to severe dementia (46). In certain circumstances, it may be helpful to ask the patients to bring in all the medications they regularly or intermittently take, and review the labels (5). Moreover, the use of drug provocation tests has some challenges in the elderly. Although topical provocation testing offers a safer alternative method than systemic provocation, it is also a less reliable diagnostic tool due to false-negative results (7). As elderly people have an age-related decline in immune functions, termed immunosenescence, caution should be exerted when interpreting the negative test results in these patients $(4,30)$. On the other hand, overpenetration of the drugs through the skin due to age-related skin atrophy may induce irritant and false-positive test reactions (4). Systemic (oral) drug provocation testing is the most reliable method of diagnosing FDE and establishing the causative drugs (7). Nevertheless, according to the European Network on Drug Allergy (ENDA) guidelines, it should not be performed in patients with comorbidities such as cardiac, hepatic, renal, or other diseases, where exposure might provoke a situation that is beyond medical control (35). This is particularly important for elderly patients with multicomorbidity and frailty which develops as a consequence of an age-related 
decline in many physiological systems (36). Frailty refers to an enhanced vulnerability to poor resolution of homeostasis after a stressor event, which increases the risk of negative health-related outcomes $(36,37)$. Therefore, oral drug provocation tests should be performed with special caution in these patients, following a careful systemic evaluation and assessment of the risk-benefit ratio (4). In our long-term clinical experience, on the other hand, oral provocation tests were performed in all patients aged between 60 and 82 years, without any complications. Importantly, topical provocation testing was not able to identify the causative drug in a majority of patients, who were then diagnosed according to the positive results of oral provocation tests with the same drugs. Our findings indicated that, when performed carefully in selected patients by experienced clinicians, systemic provocation testing was a safe method in establishing the causative drugs of FDE in this age group.

The management of elderly patients with FDE requires a multidisciplinary approach. Dermatologists and clinicians from other specialties should collaborate to prevent further attacks and develop alternative treatment schedules which do not include the implicated drugs. Moreover, both patients and their caregivers should be informed and counseled on avoidance of the culprit medications to increase adherence.

The main limitation of this study was its retrospective nature.

\section{CONCLUSION}

The present study is the first to investigate the characteristic features of FDE in elderly patients, to the best of our knowledge. Our findings highlight that FDE, although mainly reported in young adults, might also affect the elderly. FDE was induced by intermittently taken drugs in all patients, half of whom had a high burden of polypharmacy. Trimethoprim-sulfamethoxazole and NSAIDs were the most common causative drugs, while ornidazole was a remarkable novel FDE inducer since the year 2011. As a striking finding, a great majority of patients had BFDE raising the question of whether the bullous type is a more common clinical phenotype in this age group. BFDE, particularly when generalized, may pose a big diagnostic challenge as it may clinically mimic severe and potentially life-threatening drug reactions, such as Stevens-Johnson syndrome and toxic epidermal necrolysis, and autoimmune bullous diseases, such as pemphigus vulgaris and bullous pemphigoid.

Evaluation of elderly patients with FDE has unique challenges such as polypharmacy, multimorbidity, recall problems, cognitive disorders, frailty, and immunosenescence. Therefore, awareness of the clinical heterogeneity, causative drugs, and diagnostic challenges of FDE remains crucial in preventing delayed diagnosis or misdiagnosis which may lead to recurrent attacks, irrelevant investigations, overtreatments, and further impairment of quality of life in this fragile patient population.
Ethics Committee Approval: This study was approved by the Ethical Committee of the Istanbul University, Istanbul Faculty of Medicine (Date: 18.03.2021, No: 139758).

Informed Consent: Written or verbal consent was obtained from the participants.

Peer Review: Externally peer-reviewed.

Author Contributions: Conception/Design of Study- G.B.K., E.Ö.; Data Acquisition- G.B.K., E.Ö.; Data Analysis/Interpretation- G.B.K., E.Ö.; Drafting Manuscript- G.B.K., E.Ö.; Critical Revision of Manuscript- G.B.K., E.Ö.; Final Approval and Accountability- G.B.K., E.Ö.

Conflict of Interest: Authors declared no conflict of interest.

Financial Disclosure: Authors declared no financial support.

Etik Komite Onayı: Bu çalışma için etik komite onayı İstanbul Üniversitesi, İstanbul Tıp Fakültesi Etik Kurulu'ndan alınmıştır (Tarih: 18.03.2021, No: 139758).

Bilgilendirilmiş Onam: Katılımcılardan bilgilendirilmiş onam alınmıştır.

\section{Hakem Değerlendirmesi: Dış bağımsız.}

Yazar Katkıları: Çalışma Konsepti/Tasarım- G.B.K., E.Ö.; Veri Toplama- G.B.K., E.Ö.; Veri Analizi/Yorumlama- G.B.K., E.Ö.; Yazı Taslağı- G.B.K., E.Ö.; İçeriğin Eleştirel İncelemesi- G.B.K., E.Ö.; Son Onay ve Sorumluluk- G.B.K., E.Ö.

Çıkar Çatışması: Yazarlar çıkar çatışması beyan etmemişlerdir.

Finansal Destek: Yazarlar finansal destek beyan etmemişlerdir.

\section{REFERENCES}

1. World Health Organization (2011). Global Health and Aging. Available from: URL: https://www.who.int/ageing/ publications/global_health.pdf

2. United Nations, Department of Economic and Social Affairs, Population Division (2019). World Population Ageing 2019: Highlights. (ST/ESA/SER.A/430). Available from: URL: https://www.un.org/en/development/desa/population/ publications/pdf/ageing/WorldPopulationAgeing2019Highlights.pdf

3. United Nations, Department of Economic and Social Affairs, Population Division (2013). World Population Ageing 2013. (ST/ESA/SER.A/348.). Available from: URL: https://www. un.org/en/development/desa/population/publications/ pdf/ageing/WorldPopulationAgeing2013.pdf

4. Heng YK, Lim YL. Cutaneous adverse drug reactions in the elderly. Curr Opin Allergy Clin Immunol 2015;15(4):300-7. [CrossRef]

5. Davies EA, O'Mahony MS. Adverse drug reactions in special populations - the elderly. Br J Clin Pharmacol 2015;80(4):796-807. [CrossRef]

6. Carneiro SC, Azevedo-e-Silva MC, Ramos-e-Silva M. Drug eruptions in the elderly. Clin Dermatol 2011;29(1):43-8. [CrossRef] 
7. Özkaya E. Fixed drug eruption: state of the art. J Dtsch Dermatol Ges 2008;6(3):181-8. [CrossRef]

8. Patel S, John AM, Handler MZ, Schwartz RA. Fixed drug eruptions: an update, emphasizing the potentially lethal generalized bullous fixed drug eruption. Am J Clin Dermatol 2020;21(3):393-9. [CrossRef]

9. Özkaya E. Changing trends in inducer drugs of fixed drug eruption: a 20-year cross-sectional study from Turkey. J Dtsch Dermatol Ges 2018;16(4):474-6. [CrossRef]

10. Ngwasiri CA, Abanda MH, Aminde LN. Ivermectin-induced fixed drug eruption in an elderly Cameroonian: a case report. J Med Case Rep 2018;12(1):254. [CrossRef]

11. Byrd RC, Mournighan KJ, Baca-Atlas M, Helton MR, Sun NZ, Siegel MB. Generalized bullous fixed-drug eruption secondary to the influenza vaccine. JAAD Case Rep 2018;4(9):953-5. [CrossRef]

12. Paulmann M, Mockenhaupt M. Unfreiwillige Reexposition: Generalisiertes bullöses fixes Arzneiexanthem bei 2 älteren Patientinnen [Unintended rechallenge: Generalized bullous fixed drug eruption in two elderly women]. Hautarzt 2017;68(1):59-63. [CrossRef]

13. Ozkaya-Bayazit E, Akar U. Fixed drug eruption induced by trimethoprim-sulfamethoxazole: evidence for a link to HLA-A30 B13 Cw6 haplotype. J Am Acad Dermatol 2001;45(5):712-7. [CrossRef]

14. Cho YT, Lin JW, Chen YC, Chang CY, Hsiao CH, Chung $\mathrm{WH}$, et al. Generalized bullous fixed drug eruption is distinct from Stevens-Johnson syndrome/toxic epidermal necrolysis by immunohistopathological features. J Am Acad Dermatol 2014;70(3):539-48. [CrossRef]

15. Wongrakpanich S, Wongrakpanich A, Melhado K, Rangaswami J. A comprehensive review of non-steroidal anti-inflammatory drug use in the elderly. Aging Dis 2018;9(1):143-150. [CrossRef]

16. Vandraas KF, Spigset O, Mahic M, Slørdal L. Non-steroidal anti-inflammatory drugs: use and co-treatment with potentially interacting medications in the elderly. Eur J Clin Pharmacol 2010;66(8):823-9. [CrossRef]

17. Gupta S, Jain VK, Aggarwal K, Gupta S, Mahendra A. Fixed drug eruption caused by ornidazole. Contact Dermatitis 2005;53(5):300-1. [CrossRef]

18. Gupta S, Mahendra A, Gupta S, Kaur S. Multiple fixed drug eruption caused by ornidazole. Dermatitis 2010;21(6):330-3. [CrossRef]

19. Sanmukhani J, Shah V, Baxi S, Tripathi C. Fixed drug eruption with ornidazole having cross-sensitivity to secnidazole but not to other nitro-imidazole compounds: a case report. Br J Clin Pharmacol 2010;69(6):703-4. [CrossRef]

20. Marya CM, Sharma G, Parashar VP, Dahiya V. Mucosal fixed drug eruption in a patient treated with ornidazole. J Dermatol Case Rep 2012;6(1):21-4. [CrossRef]

21. Gupta R. Fixed drug eruption due to ornidazole. Indian J Dermatol 2014;59(6):635. [CrossRef]

22. Emre $\mathrm{S}$, Ahsen $\mathrm{H}$, Aktaş A. Ornidazole-induced fixed drug reaction on sole: case report and review of the literature. Cutan Ocul Toxicol 2017;36(3):294-6. [CrossRef]
23. World Health Organization (2019). Medication Safety in Polypharmacy. (WHO/UHC/SDS/2019.11). Available from: URL: https://apps.who.int/iris/bitstream/handle/10665/325454/ WHO-UHC-SDS-2019.11-eng.pdf?ua=1

24. Pazan F, Wehling M. Polypharmacy in older adults: a narrative review of definitions, epidemiology and consequences. Eur Geriatr Med 2021 Mar 10. [CrossRef]

25. Ozkaya-Bayazit E. Specific site involvement in fixed drug eruption. J Am Acad Dermatol 2003;49(6):1003-7. [CrossRef]

26. Özkaya E. Oral mucosal fixed drug eruption: characteristics and differential diagnosis. J Am Acad Dermatol 2013;69(2):e51-8. [CrossRef]

27. Fourzali KM, Yosipovitch G. Management of itch in the elderly: a review. Dermatol Ther (Heidelb) 2019;9(4):639-53. [CrossRef]

28. ZaouakA, Ben Salem F, Ben Jannet S, Hammami H, Fenniche S. Bullous fixed drug eruption: A potential diagnostic pitfall: a study of 18 cases. Therapie 2019;74(5):527-30. [CrossRef]

29. Ben Fadhel N, Chaabane A, Ammar H, Ben Romdhane $H$, Soua $Y$, Chadli $Z$, et al. Clinical features, culprit drugs, and allergology workup in 41 cases of fixed drug eruption. Contact Dermatitis 2019;81(5):336-40. [CrossRef]

30. Pai W, Kikkeri NN, Athanikar SB, Shukla P, Bhandari P, Rai $\mathrm{V}$. Retrospective analysis of fixed drug eruptions among patients attending a tertiary care center in Southern India. Indian J Dermatol Venereol Leprol 2014;80(2):194. [CrossRef]

31. Jung JW, Cho SH, Kim KH, Min KU, Kang HR. Clinical features of fixed drug eruption at a tertiary hospital in Korea. Allergy Asthma Immunol Res 2014;6(5):415-20. [CrossRef]

32. Brahimi N, Routier E, Raison-Peyron N, Tronquoy AF, Pouget-Jasson C, Amarger S, et al. A three-year-analysis of fixed drug eruptions in hospital settings in France. Eur J Dermatol 2010;20(4):461-4. [CrossRef]

33. Cho YT, Lin JW, Chen YC, Chang CY, Hsiao CH, Chung $\mathrm{WH}$, et al. Generalized bullous fixed drug eruption is distinct from Stevens-Johnson syndrome/toxic epidermal necrolysis by immunohistopathological features. J Am Acad Dermatol 2014;70(3):539-48. [CrossRef]

34. Weiskopf D, Weinberger B, Grubeck-Loebenstein B. The aging of the immune system. Transpl Int 2009;22(11):104150. [CrossRef]

35. Aberer W, Bircher A, Romano A, Blanca M, Campi P, Fernandez J, et al. European Network for Drug Allergy (ENDA); EAACl interest group on drug hypersensitivity. Drug provocation testing in the diagnosis of drug hypersensitivity reactions: general considerations. Allergy 2003;58(9):854-63. [CrossRef]

36. Clegg A, Young J, Iliffe S, Rikkert MO, Rockwood K. Frailty in elderly people. Lancet 2013;381(9868):752-62. [CrossRef]

37. Cesari M, Calvani R, Marzetti E. Frailty in older persons. Clin Geriatr Med 2017;33(3):293-303. [CrossRef] 